\title{
Study the prey preference of some aquatic insects for different snails under the laboratory conditions
}

Mohamed Z. Y. Aly; Ibrahim E. E.Mohamed; and Shadia M. Bakry

Zoology Department (Entomology), Faculty of Science (Qena), South Valley University

ABSTRACT

The study of five aquatic insects (predators), adults of two hemipterous species, Limnogeton fieberi Mayr, Sphaerodema urinator Duf., and nymphs of three Odonatous species, Anax imperator Leach, Crocothemis erythraea Brulle and Ischnura pumilio Charp. on four species of snails (preys) exist in its natural habitat at Qena, Bulinus truncates Audouin, Biomphalaria alexandrina Ehrenb, Cleopatra bulimoides Olivier and Melanoides tuberculata Muller. in non choice experiment under laboratory conditions, the result indicated that the first preference for attack to all predators was directed towards $B$. truncates. And the last preference was $B$. alexandrina. Except, L. fieberi, the last preference was C. bulimoides.

Keywords: aquatic insects, snails, predation.

\section{INTRODUCTION}

In Egypt, aquatic snails infest rice plant. Hassan and Kalliny, (1967); Lutfallah, (1974) and some of them serve as intermediate hosts of some parasitic diseases such as Schistosoma mansoni Sambon, S. haematobium Bilharz, Fasciala hepatica L. and Angiostrongylus cantonensis Chen. Azzam (1987). These make the control of these pests very important for the agriculture and health of human and domestic animals. It has been almost universally agreed that the best possible method for controlling molluscs is the utilization of the naturally occurring biological control agents (NOBCA).

The present study is an attempt to demonstrate number of predators deployed in the ponds and marshes in the governorate of Qena to determine the prey preference by using predators under laboratory conditions. Therefore, Five aquatic predators were collected from the field. They were identified as adults of two hemipterous species, Limnogeton fieberi Mayr, Sphaerodema urinator Duf. (Belostomatidae), and nymphs of three Odonatous species, Anax imperator Leach (Aeshnidae), Crocothemis erythraea Brulle (Libellulidae) and Ischnura pumilio Charp.(Coenagrionidae), as shown in photos $(1,2,3,4$ and 5$)$

The preys were medically and veterinary important fresh water snails in Egypt include: Bulinus truncates Audouin (Planorbidae) it acts the main intermediate host of Schistosoma haematobium in Egypt and Middle East countries. Rysavy et al. (1974), Biomphalaria alexandrina Ehrenb.(Planorbidae), it acts as an intermediate host of Shistosoma mansoni in Egypt. Previously publications indicated that this snail was widely distributed in the Nile Delta only, while recent reports and the present survey indicated that it has invaded Upper Egypt till Aswan after building the High Dam, Cleopatra bulimoides Olivier (Thiaridae), it acts as intermediate host for Gastrodiscus aegypticus and Prohemistomum vivax, as well as several other trematodes, it is edible by many bottom feeding fishes and Melanoides tuberculata Muller (Thiaridae), it harbours several species of cercariae, it acts as first intermediate 
host for Lecithodendrium pyramidum, which has the adult stage in bats, it is edible by bottom feeding fishes.

The aim of the present study using the Egyptian fresh water predatory insects, acting as biological control agents for snails which are intermediate hosts for some parasitic diseases of human and domestic animals under laboratory conditions, and Study the preference of predators towards the different snails species which exist in its natural habitat.

\section{MATERIAL AND METHODS}

The study of aquatic insects associated with harmful snails in fresh water habitats were carried out through irregular samples collected from Qena city, during the period (2007-2010). Under laboratory conditions, the present work examine the consumption capacity of the predators (insects) on the preys (snails).

An experiments were conduced in the laboratory to study the preference of predators towards the different snails species which exist in its natural habitat. This group of snails consisted of the following species B. truncates, B. alexandrina, $M$. tuberculata and C. bulimoide, as shown in photos (6,7,8 and 9)

Five individuals of the predators (the same species) were isolated in plastic container, filled with field water, five containers were used, and covered by a perforated membranous plastic cover to prevent escaping of insects, Abou El- Ela et. al. (2003). All aquaria was oxygenated using air pumps and received indirect solar illumination through windows, and the water was changed (every alternate day) to avoid fouling of water and the results observed daily at the same time for ten days.

Twenty individuals of each snail species were introduced to each container $(80$ snails in the container from the four species), and provided with electric wires and floating foam rubber pieces in water for the insect to crawl and settle on instead of aquatic grasses and plants used by other investigators to avoid fermentation of plants and keeping water quality and the daily number of consumed snails by each species was replaced, after being counted by an equal number of fresh individuals.

Before starting the experiment, the predators were starved for two days. The number of preys consumed for $24 \mathrm{~h}$ was noted, and an equivalent number of snails replenished to the experimental sets. The $\mathrm{pH}$ value, laboratory temperature and water temperature were recorded daily during the period of experiment. Rearing of aquatic snails were made by the same technique described by Azzam and Tawfik (1997).

This procedure was repeated throughout period of ten days, at the end of treatment, the snail species showing the highest consumption (i.e. most preferred) was eliminated. The remaining species of snails were treated similarly for another ten days to eliminate the following preferred species and so on, until investigating the least preferred one, with recording the room temperature, water temperature and $\mathrm{pH}$ value. When the level of preference was represented by three snail species, twenty five snail from each species were introduced instead of twenty, and when the level represented by two snail species, forty of each were introduced.

\section{RESULTS}

In the laboratory, predation test was achieved to determine the malacophagous species, and the insects may act as biological control agents for snails which are intermediate hosts for some parasitic diseases of human and domestic animals under 
laboratory conditions. The data of these treatments were analyzed by the program (statistical package for social science) (SPSS).

\section{Prey preference}

\section{1- Consumption capability of four snails by each predator in non choice experiment under laboratory conditions:}

The experiment was conducted in the laboratory to study the preference of the five predators (L. fieberi, S. urinator, A. imperator, C. erythraea and I. pumilio) against the four types of snails which exist in its natural habitat, $B$. truncates, $B$. alexandrina, $M$. tuberculata, and C. bulimoides.

The consumption capability of the predators in non choice experiment under laboratory conditions (T.30-37, T.W.27-29, pH.7.5-8.5) on four snails (preys), as shown in table (1) and figure (1) as follow:

Table 1: Average number of four consumed snails by each predator in non choice experiment under laboratory conditions (T.30-37, T.W.27-29, pH.7.5-8.5) at Qena

\begin{tabular}{|c|c|c|c|c|c|c|}
\hline preys & Bulinus & Biomphalaria & Cleopatra & Melanoides & Mean & F. value \\
Predators & & & & & & \\
\hline Limnogeton & ${ }^{\varrho} 14.38 \mathrm{~A}$ & $8.42 \mathrm{~B}$ & $7.24 \mathrm{C}$ & $7.92 \mathrm{C}$ & $9.54 \mathrm{a}$ & $190.4^{* *}$ \\
fieberi & \pm 0.82 & \pm 0.60 & \pm 0.47 & \pm 0.48 & \pm 3.57 & \\
\hline Sphaerodema & $12.48 \mathrm{~A}$ & $4.34 \mathrm{D}$ & $6.00 \mathrm{C}$ & $6.98 \mathrm{~B}$ & $7.45 \mathrm{bc}$ & \\
urinator & \pm 1.37 & \pm 0.46 & \pm 0.80 & \pm 0.48 & \pm 3.33 & $296.0^{* *}$ \\
\hline Anax & $13.14 \mathrm{~A}$ & $5.26 \mathrm{C}$ & $5.96 \mathrm{~B}$ & $6.36 \mathrm{~B}$ & $7.68 \mathrm{~b}$ & \\
imperator & \pm 0.95 & \pm 1.28 & \pm 0.80 & \pm 0.70 & \pm 3.80 & $299.2^{* *}$ \\
\hline Crocothemis & $11.05 \mathrm{~A}$ & $4.86 \mathrm{D}$ & $5.86 \mathrm{C}$ & $7.06 \mathrm{~B}$ & $7.21 \mathrm{c}$ & \\
erthyrea & \pm 1.13 & \pm 0.79 & \pm 0.86 & \pm 0.86 & \pm 3.23 & $221.5^{* *}$ \\
\hline Ischnura & $9.04 \mathrm{~A}$ & $4.22 \mathrm{D}$ & $5.62 \mathrm{C}$ & $7.02 \mathrm{~B}$ & $6.48 \mathrm{~d}$ & \\
pumilio & \pm 1.61 & \pm 0.58 & \pm 0.93 & \pm 0.61 & \pm 3.18 & $168.0^{* *}$ \\
\hline Mean & $12.06 \mathrm{~A}$ & $5.42 \mathrm{D}$ & $6.14 \mathrm{C}$ & $7.07 \mathrm{~B}$ & & \\
& \pm 1.14 & \pm 1.50 & \pm 0.507 & \pm 0.764 & & \\
\hline
\end{tabular}

F. value: $\mathrm{A}($ snails $)=1076.3^{* *} \mathrm{~B}(\mathrm{pr})=.123.5^{* *} \mathrm{AB}=23.59^{* *} @=$ Based on (10 days $\mathrm{x} 5$ replicates).

F. Test: (ns) $=$ not significant $*=$ sign. at $5 \%$ level of probability $* *=$ highly sign. at $1 \%$ level of prob. $\pm=(\mathrm{sd})$ standard deviation

Means followed by the same letter in each row or column are not significantly different at 0.05 level of probability, by Duncan's multiple range test.

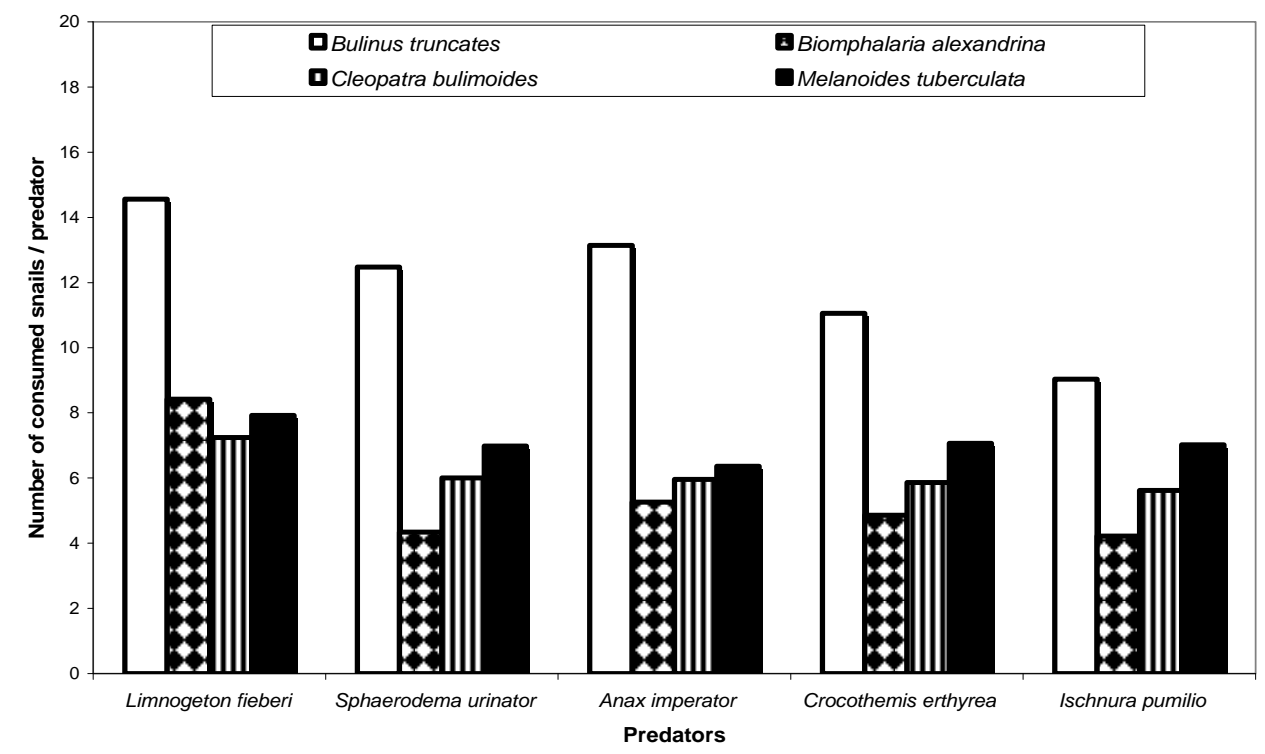

Fig. 1: Average number of four consumed snails by each predator in non choice experiment under laboratory conditions.

Regarding to a comparison between the consumption capability of the five predators on four types of snails, the maximum consumed number of the snails 
(preys) was represented by Limnogeton fieberi (mean=9.54a \pm 3.57 ), while the minimum number was observed in case of the predator Ischnura pumilio (mean $=6.48 \mathrm{~d} \pm 3.18$ ). These results were confirmed statistically as highly significance at $0.1 \%$ probability level of error for predation of the present predator.

On the other hand, regarding to a comparison between the four consumed snails by the five predators, the maximum consumed number of the snails (preys) was represented by Bulinus truncates (mean $=12.06 \mathrm{~A} \pm 1.14$ ), while the minimum number was observed in case of Biomphalaria alexandrina, (mean $=5.42 \mathrm{D} \pm 1.50)$. These results were confirmed statistically as highly significance at $0.1 \%$ probability level of error for predation of the present predators.

Thereby, the result indicated that when all predators were provided with equal numbers of the snails species recorded above, the first preference for attack was directed towards Bulinus truncates. However, at the case of $L$. fieberi, the tested preys could be arranged descending according to the preference as follows: B. truncates, $B$. alexandrina, M. tuberculata and lastly C. bulimoides. On the other hand, at the case of other predators, the tested preys could be arranged descending according to the preference as follows: B. truncates, M. tuberculata, $C$. bulimoides and lastly $B$. alexandrina.

\section{2- Consumption capability of three snails by each predator in non choice experiment under laboratory conditions:}

The experiment was repeated again in the laboratory to study the preference of the five predators against the three types of snails which exist in its natural habitat, $B$. alexandrina, $M$. tuberculata, and $C$. bulimoides, after isolated the preference snail $B$. truncates.

The consumption capability of the predators in non choice experiment under laboratory conditions (T.29-35, T.W.25-28, pH.7-8.5) on three snails (preys), as shown in table (2) and figure (2) as follows:

Regarding to a comparison between the consumption capability of the five predators on three types of snails, the maximum consumed number of the snails (preys) was represented by Limnogeton fieberi (mean=12.31a \pm 4.21 ), while the minimum number was observed in case of the predator Ischnura pumilio $($ mean $=7.07 \mathrm{~b} \pm 2.56)$.

Table 2: Average number of three consumed snails by each predator in non choice experiment under laboratory conditions (T. 29-35, T.W.25-28, pH.7-8.5) at Qena

\begin{tabular}{|c|c|c|c|c|c|}
\hline Predators & $\begin{array}{c}\text { Biomphalaria } \\
\text { alexandrina }\end{array}$ & $\begin{array}{l}\text { Cleopatra } \\
\text { bulimoides }\end{array}$ & $\begin{array}{l}\text { Melanoides } \\
\text { tuberculata }\end{array}$ & Mean & F. value \\
\hline Limnogeton fieberi & $\begin{array}{c}(17.04 \mathrm{~A} \\
\pm 0.82\end{array}$ & $9.64 \mathrm{~B}$ & $10.24 \mathrm{~B}$ & $12.31 \mathrm{a}$ & \\
& $4.98 \mathrm{C}$ & $6.44 \mathrm{~B}$ & $11.08 \mathrm{~A}$ & $7.50 \mathrm{~b}$ & \\
& \pm 0.61 & \pm 0.65 & \pm 1.14 & \pm 3.28 & $267.1 * *$ \\
\hline Sphaerodema & $5.14 \mathrm{C}$ & $6.24 \mathrm{~B}$ & $11.32 \mathrm{~A}$ & $7.57 \mathrm{~b}$ & \\
urinator & \pm 1.09 & \pm 0.79 & \pm 1.67 & \pm 3.13 & $105.1 * *$ \\
\hline Anax imperator & $5.00 \mathrm{C}$ & $7.30 \mathrm{~B}$ & $9.86 \mathrm{~A}$ & $7.40 \mathrm{bc}$ & \\
& \pm 0.59 & \pm 1.06 & \pm 0.60 & \pm 2.60 & $204.0^{* *}$ \\
\hline Crocothemis & $5.06 \mathrm{C}$ & $7.20 \mathrm{~B}$ & $8.96 \mathrm{~A}$ & $7.07 \mathrm{~b}$ & \\
erthyrea & \pm 0.69 & \pm 1.06 & \pm 0.60 & \pm 2.56 & $182.3 * *$ \\
\hline Ischnura pumilio & $7.43 \mathrm{~B}$ & $7.37 \mathrm{~B}$ & $10.29 \mathrm{~A}$ & & \\
\hline Mean & \pm 5.37 & \pm 1.53 & \pm 0.535 & & \\
\hline
\end{tabular}

F. value: $\mathrm{A}$ ( snails) $=291.3^{* *} \mathrm{~B}$ (pr.) $=307.6^{* *} \mathrm{AB}=177.3^{* *} @=$ Based on (10 days x 5 replicates).

F. Test: $(\mathrm{ns})=$ not significant $*=$ sign. at $5 \%$ level of probability $* *=$ highly sign. at $1 \%$ level of prob.

$\pm=(\mathrm{sd})$ standard deviation

Means followed by the same letter in each row or column are not significantly different at 0.05 level of probability, by Duncan's multiple range test. 


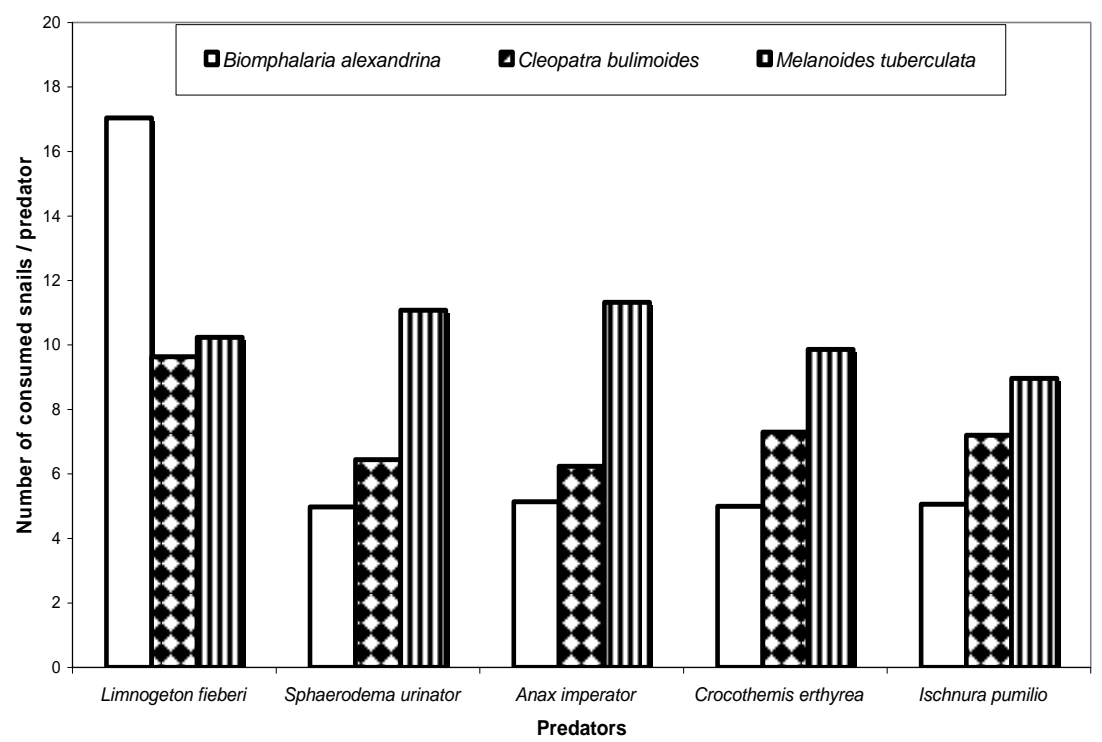

Fig. 2: Average number of three consumed snails by each predator in non choice experiment under laboratory conditions.

With observation that, there is no significant between the four predators, Sphaerodema urinator, Anax imperator, Crocothemis erythraea and Ischnura pumilio, which take the same letter (b).

These results were confirmed statistically as highly significance at $0.1 \%$ probability level of error for predation of the present predators.

On the other hand, regarding to a comparison between the three consumed snails by the five predators, the maximum consumed number of the snails (preys) was represented by Melanoides tuberculata (mean=10.29A \pm 0.535 ), while the minimum number was observed in case of Biomphalaria alexandrina and Cleopatra bulimoides, there is no significant between them. These results were confirmed statistically as highly significance at $0.1 \%$ probability level of error for predation of the present predators.

Thereby, the result indicated that when all predators were provided with equal numbers of the three snails species recorded above, the first preference for attack was directed towards Melanoides tuberculata. however, the tested preys could be arranged descending according to the preference by Limnogeton fieberi as follows: $B$. alexandrina, $M$. tuberculata and lastly C. bulimoides. But the other four predators the tested preys could be arranged as follows: $M$. tuberculata, $C$. bulimoides and lastly $B$. alexandrina. These results showed that the important role played by the predators under investigation in controlling these harmful snails.

3- Consumption capability of two snails by each predator in non choice experiment under laboratory conditions:

The experiment was repeated again in the laboratory to study the preference of the five predators against the two types of snails which exist in its natural habitat. The two snails $M$. tuberculata, and C. bulimoides were introduced to Limnogeton fieberi after isolated the preference snails $B$. truncates and $B$. alexandrina. The result indicated that the tested preys could be arranged as follows: $M$. tuberculata and lastly C. bulimoides.

The two snails B. alexandrina and C. bulimoides were introduced to other four predators after isolated the preference snails $B$. truncates and $M$. tuberculata. The result indicated that the tested preys could be arranged as follows: $C$. bulimoides and lastly B. alexandrina. 
At the end of experiment, resulted that the last snail was Cleopatra bulimoides at the case of Limnogeton fieberi, but at the case of the other four predators was Biomphalaria alexandrina.

These results showed that the important role played by the predators under investigation in controlling these harmful snails.

Moreover, the statistic analysis on the influence of the predators activity supported this result. However, the predation process was in the maximum activity under the laboratory conditions.

\section{DISCUSSION}

1. Consumption capability of four snails by each predator in non choice experiment under laboratory conditions:

From the results, the study reached to the species of snails preferred for five predators L. fieberi, S. urinator, A. imperator, C.erythraea and I. pumilio under laboratory conditions in non choice experiment (there is no determine to any type of snail).

In Table (1) and Figure (1) showed the maximum consumed number of the snails (preys) was represented by Limnogeton fieberi, this may be confirmed the important role of this insect. It appeared that Bulinus truncates which the intermediate host of Schistosoma haematobium, Bilharz was highly preferable snail species to these predators which probably were attacked easily. Furthermore, they had a wide caller aperture. This result agrees with Tawfik et al. (2001).

While the minimum consumed number of the snails (preys) was represented by Ischnura pumilio, It appeared that Biomphalaria alexandrina which the intermediate host of Shistosoma mansoni in Egypt was lastly preferable snail species to these predators which the snails of Biomphalaria alexandrina could protect themselves by doing contraction retracting their soft body parts inside the shell, where the rostrum of the insects was too short to reach to the retracted soft parts, the narrow caller aperture of the shell helped the snails to protect themselves well. The last reason was noticed by Kesler and Munns (1989), and Osman (2001). These results were confirmed statistically as highly significance at $0.1 \%$ probability level of error for predation of the present predator.

\section{Consumption capability of three snails by each predator in non choice} experiment under laboratory conditions:

In Table (2) and Figure (2) showed the maximum consumed number of the snails (preys) was represented also by Limnogeton fieberi, this may be confirmed the last results. It appeared that Melanoides tuberculata which the intermediate host of Lecithodendrium pyramidum, was highly preferable snail species to these predators after isolated the Bulinus truncates from the experiment which probably were attacked easily. Furthermore, they had oval aperture, forming about $1 / 3$ of the total length of the shell. But it appeared that Biomphalaria alexandrina was the second preferable snail to Limnogeton fieberi. This result agrees with that obtained by Hairston et.al.(1975) which cleared that the water bugs Limnogeton fieberi use for controlling the snails Biomphalaria glabrata and physella acuta.

Limnogeton fieberi (the only insect) prefer the snail of Biomphalaria alexandrina after the snail of Bulinus truncates. This result agrees with that recorded by Awadallah et al. (1991) who studied the biology of the Limnogeton fieberi Mayr in association with the two snail species Biomphalaria alexandrina and Hetisoma duryi. It appeared that B. alexandria, the intermediate host of Schistosoma mansoni, is more 
adequate prey than $H$. duryi and accordingly it could be considered one of the efficient biological control agents of this harmful snail.

large Belostoma species showed a remarkable preference for snails as a food source. These groups of species are successful in preying on snails due to the specialized characteristics of their heads such as the presence of anteoculus which is longer than their interoculus and a slender and long beak, enabling the styletes to be inserted deeper into the shells thus reaching the retracted body of Biomphalaria. The effectiveness of Belostoma species preying on snails needs to be studied in the field in order to know if these insects populations may have a controlling effect on snails population, Armua de Reyes (2006).

While the minimum consumed number of the snails (preys) was represented by the other four predators, Sphaerodema urinator, Anax imperator, Crocothemis erythraea and Ischnura pumilio, which there are no significant between them, and it appeared that Biomphalaria alexandrina and Cleopatra bulimoides were the lastly preferable snails species to these predators in this experiment, which there is no significant between these snails. These result were confirmed statistically as highly significance at $0.1 \%$ probability level of error for predation of the present predator.

\section{CONCLUSION}

Limnogeton fieberi Mayr may well be employed in controlling these snails. Since successful biological control depends on the selection of a natural enemy having high degree of host specificity or preference.

Ischnura pumilio Charp. May well be employed in controlling these snails. But lower than the other predators under laboratory conditions.

It appeared that Bulinus truncates which the intermediate host of Schistosoma haematobium, Bilharz was highly preferable snail species to these predators.

It appeared that Biomphalaria alexandrina which the intermediate host of Schistosoma mansoni Bilharz, may be the lastly preferable snail species to these predators. Except, the case of Limnogeton fieberi, Biomphalaria alexandrina acts the second preferable snail species.

The Belostomatidae (Limnogeton fieberi and Sphaerodema urinator), and Odonata (Anax imperator, Crocothemis erythraea and Ischnura pumilio), were active as predators of harmful snails (Bulinus truncates, Melanoides tuberculata, Biomphalaria alexandrina and Cleopatra bulimoides) thus they can be reared in large numbers and then released in the breeding places of snails in nature to achieve biological control of these pests. So, the results of such studies would enable us to formulate the biological control programme in a more effective way.

There is no doubt that putting a predator in close contact with its prey in a "microworld" such as a little bowl in the laboratory, does not give an indication that this predator may attack and feed upon the concerned prey in the nature. Baldwin et al. (1955); Bates, (1965) and Bay, (1974).

Finely, The current study hope that this study along with the aforementioned studies provide a better understanding of this promising biocontrol agent and the best conditions for rearing and releasing of this important predator of snails..

\section{REFERENCES}

Abou El- Ela, R.G.; Ibrahim, A. A.; Ramdan, R.H. and Abd-El-Aziz, M. F. (2003): Factors that may affect the role of Sphaerodema urinator Duf. As a mosquito 
predator. J. Egypt. Acad. Soc. Environ. Develop. (A-Entomology), 3(2):83100.

Armua de Reyes, A.C.A. and Estévez, A.L. (2006): Predation on Biomphalaria sp. (Mollusca: Planorbidae) by three species of the genus Belostoma (Heteroptera : Belostomatidae). Braz. J. Biol., 66(4): 1033-1035.

Awadalla, K.T.; Tawfik, M.F.S.; Youssef, F. and Azzam, K.M. (1991): Biological Studies on the Malacophagous predato Limnogeton fiberi Mayr (Hemiptera: Belostomatidae). Egyption society for Biological control of pests, 1(1): 93

Azzam, K.H. (1987): Studies on the predatory insects of Bilharziasis snails in Egypt. M.Sc.Thesis, Fac. Agr.Cairo University.

Azzam, K. M. and Tawfik, M.F.S. (1997): Effect of water temperature on some biological aspects of the malacophagous insect Sphaerodema urinator Duf. (Hemiptera: Belstomatidae). Egypt. J. Biol. Pest Control, 7(1): 91 - 96.

Baldwin, W.F.; James, H.G. and Welch, H.E. (1955): A study of mosquito larvae and pupa with a radio-active tracer. Canadian Ent., 87: 350 - 356.

Bates, M. (1965): The natural historyof mosquitoes. Harper Trochbooks. Harper \& Row Publishers, New York, pp.157-162.

Bay, E.C. (1974): Predator- prey relationships among aquatic insects. Ann. Rev. Entomol. 19: 441 - 453.

Hairston, N.G.; Wuzzinger, K.H. and Burch, J. B. (1975): Non-chemical methods of snail control. Who/ vbc 75.573, Who /Schisto / 75 (40): 1-30.

Hassan, M.S. and Kalliny, A.S. (1967): Preliminary studies on the biology of the fresh water snail, Lanistes carinatus Oliver, injurious brice in U.A.R.Res. Rev., 4(2): 185 - 193.

Kesler, D.H. and Munns, J.W.R. (1989): Predation by Belostoma flumineum (Hemiptera): an important cause of mortality in freshwater snails. J.N. Amer. Benthol. Soc., 8: 342-350.

Lutfallah, A. F. (1974): Studies on the aquatic insects in rice nurseries and Field. M. Sc. Thesis., Fac. of Agric. Cairo univ. 168 pp.

Osman, K.S.M. (2001): Ecological studies on aquatic Hemiptera collected from Qena and Aswan Governorates and their ecosystem relationship. Ph.D. in Zoology,Thesis, Fac. Sci. S.V.U.

Rysavy, F.; Moravec, F.; Barus, V. and Yousif, F. (1974): Some helminthes of Bulinus truncates and Biomphalaria alexandrina from the irrigation system near Cairo. Folia Parasitologica ( Praha ), 21 : 97 - 106.

Tawfik, M.F.S.; Awadalla, K.T.; Yousif, F. and Azzam, K.N.(2001): Biological studies on Sphaerodema urinater Duf. fed on snails. Egyptian Journal of Biological Pest, Control 11(1/2): 25-29. 

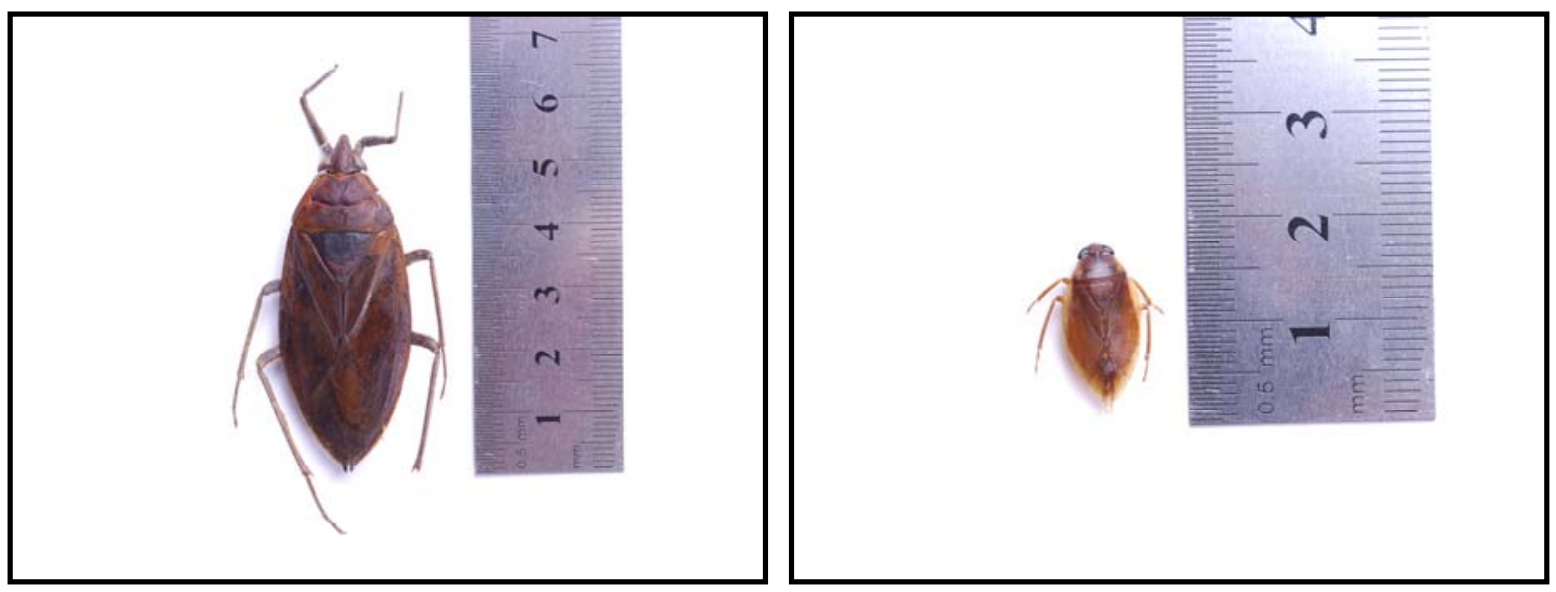

Photo. 1: Adult of Limnogeton fieberi Mayr

Photo. 2: Adult of Sphaerodema urinator Duf.

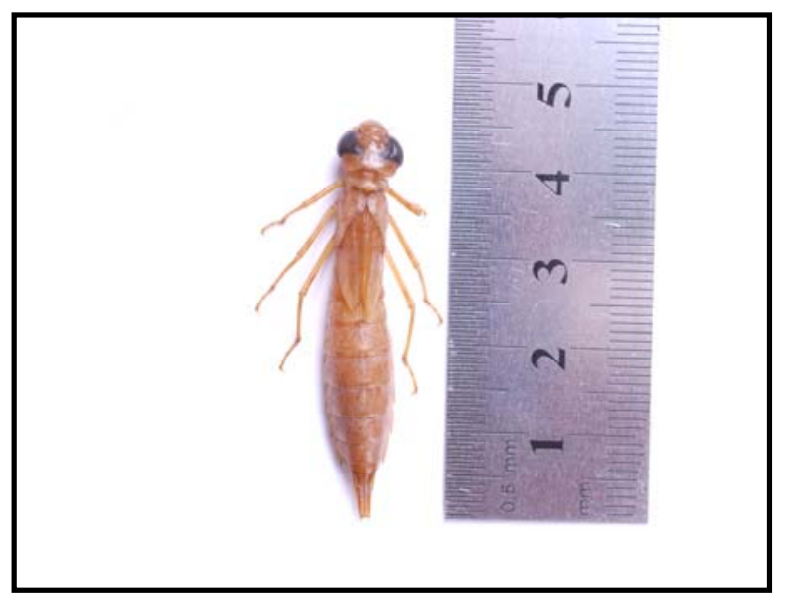

Photo. 3: nymph of Anax imperator Leach

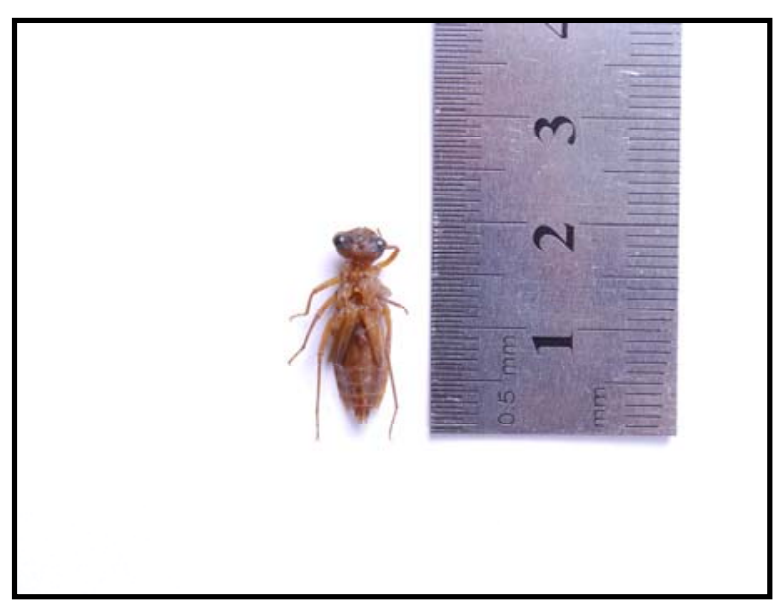

Photo. 4: nymph of Crocothemis erythraea Brulle

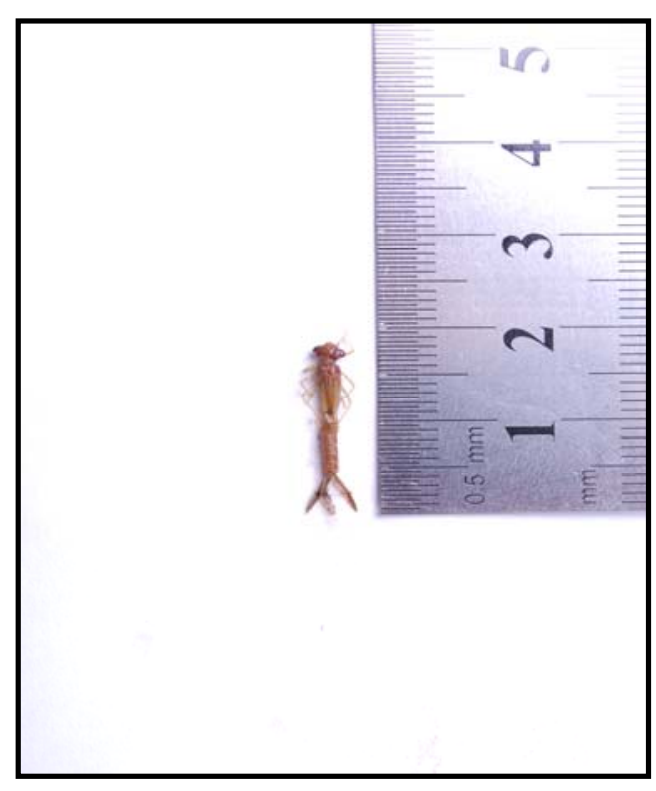

Photo. 5: Nymph of Ischnura pumilio Charp. 


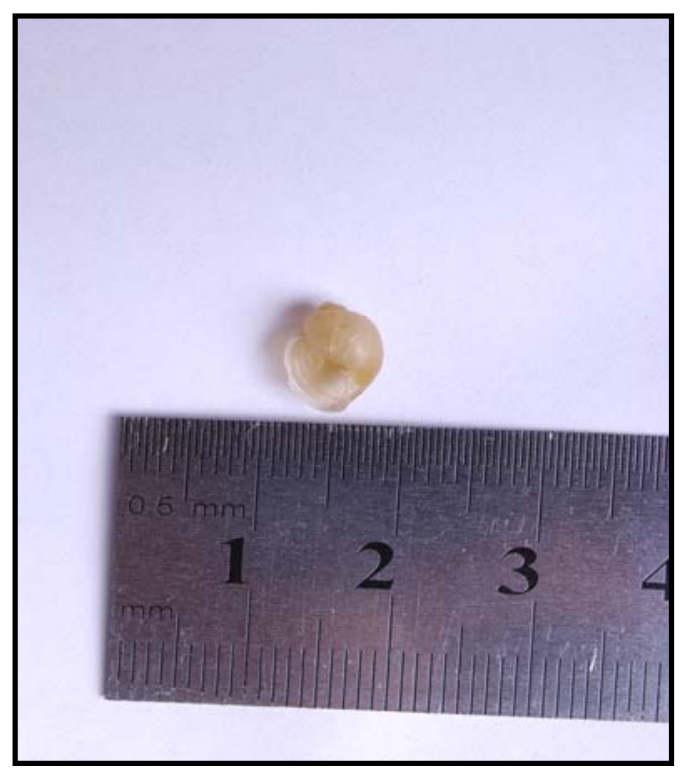

Photo. 6: Bulinus truncates Audouin

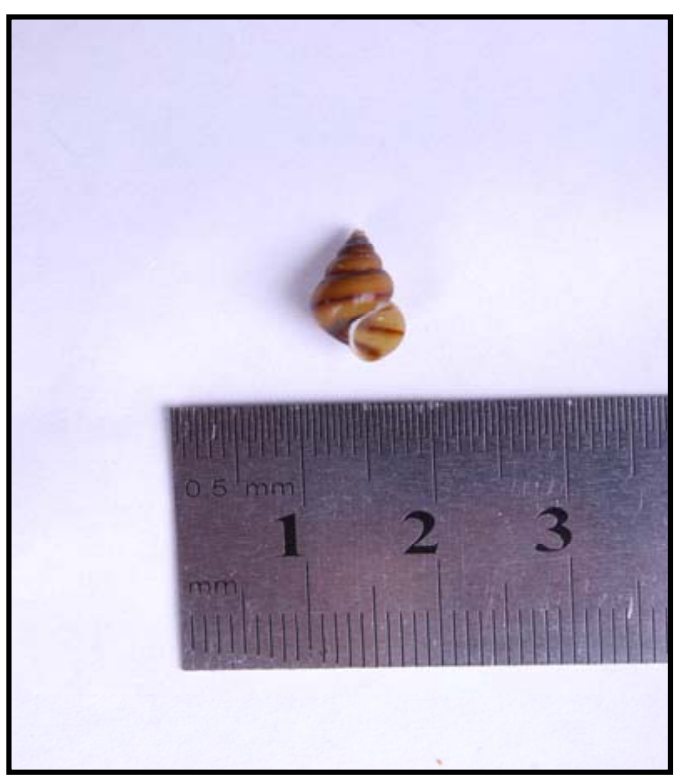

Photo. 8: Cleopatra bulimoides Olivier

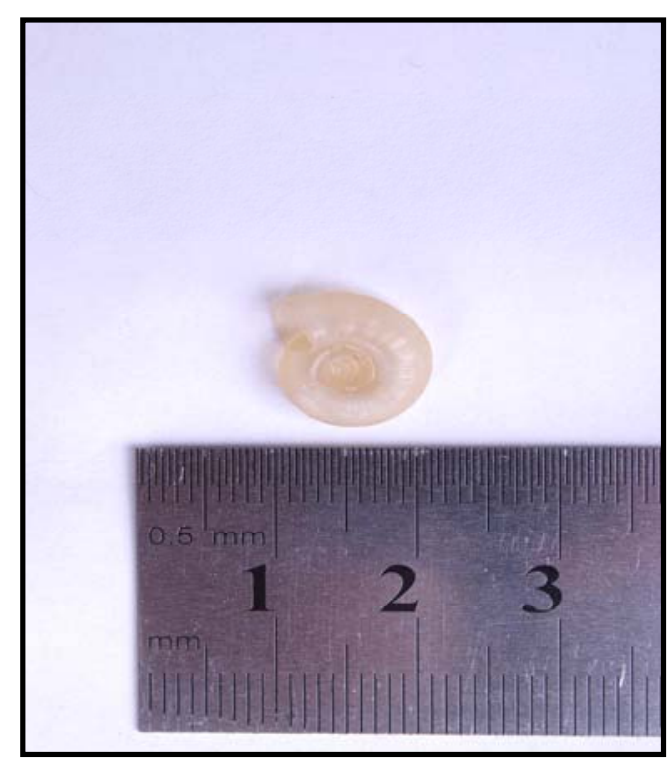

Photo. 7: Biomphalaria alexandrina Ehrenb.

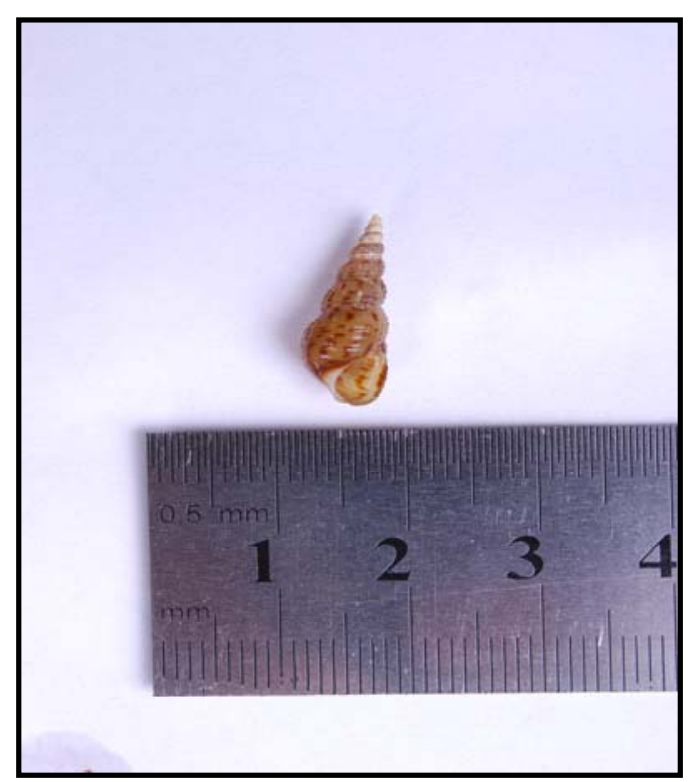

Photo. 9: Melanoides tuberculata Muller 


\section{ARABIC SUMMARY}

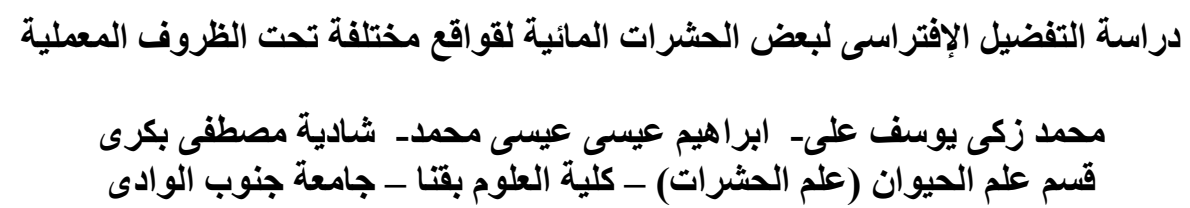

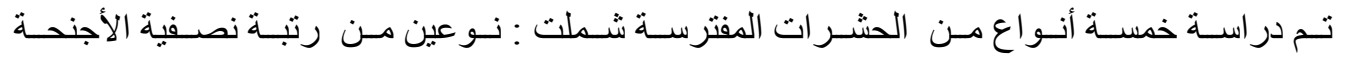

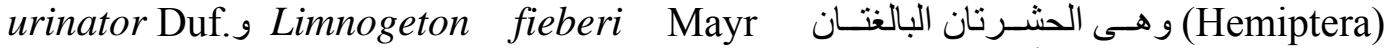
Odonata Anax imperator و وثناثة أنواع من الحوريـات تابعة لرتبـة الر عاشـات Sphaerodema هذه Leach, rocothemis erythraea Brulle and Ischnura pumilio Charp. هذه الأنواع من الحشرات ضد أربعة أنواع من القواقع الضارة كفر ائس وشملت: Bulinus truncates, Biomphalaria alexandrina Cleopatra bulimoides, and Melanoides tuberculata

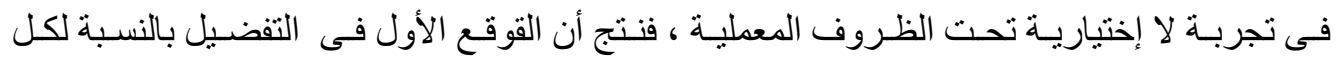

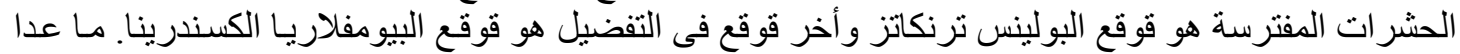
حشرة ليمنجتون فيبيرى فكان أخر قوقع فى التفضيل هو قوقع كليوباتر البيولئ ليمويدس. 